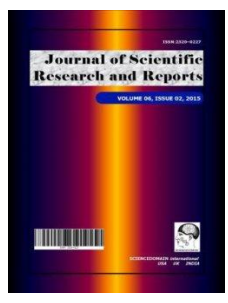

Journal of Scientific Research \& Reports

14(2): 1-11, 2017; Article no.JSRR.33285

ISSN: 2320-0227

SCIENCEDOMAIN international

www.sciencedomain.org

\title{
Phosphor Removal from Waste Water Using Hydrodynamic Cavitation
}

\begin{abstract}
K. Dölle ${ }^{1^{*}}$ and M. Van Bargen ${ }^{1}$
${ }^{1}$ Division of Environmental Science, Department of Paper and Bioprocess Engineering (PBE), College of Environmental Science and Forestry (ESF), State University of New York (SUNY),

Syracuse, New York, 13210, USA.

Authors' contributions

This work was carried out in collaboration between both authors. Author MVB wrote the first draft of the manuscript. Author KD wrote the final draft and approved the final manuscript.

Article Information

DOI: $10.9734 / J S R R / 2017 / 33285$

Editor(s):

(1) Leszek Labedzki, Institute of Technology and Life Sciences, Kujawsko-Pomorski Research Centre, Poland.

Reviewers:

(1) Saima Fazal, South China University of Technology, China.

(2) Surabhi Srivastava, School of Civil Engineering, University of Kwazulunatal, Durban, South Africa

(3) V. S. Moholkar, Indian Institute of Technology Guwahati, India. Complete Peer review History: http://www.sciencedomain.org/review-history/19014
\end{abstract}

Original Research Article

Received $7^{\text {th }}$ April 2017

Accepted 6 $6^{\text {th }}$ May 2017

Published 11 ${ }^{\text {th }}$ May 2017

\begin{abstract}
Hydrodynamic cavitation principle was applied to phosphate containing water and waste water. A $20 \%$ Calcium hydroxide slurry was applied before hydrodynamic cavitation to precipitate calcium phosphate by reacting calcium hydroxide and phosphate in water. A $70 \%$ reduction of phosphate in waste water is observed compared to controls runs using orifice plate and jet nozzle designs to produce cavitation. The jet nozzle design showed best results of for phosphate reduction in waste water. After cavitation calcium hydroxide, rich treated waste water was settled and then naturalized with carbon dioxide gas.
\end{abstract}

Keywords: Hydrodynamic cavitation; phosphor; waste water; water treatment.

*Corresponding author: E-mail: kdoelle@esf.edu; 


\section{INTRODUCTION}

Phosphorus abundance in wastewater has negative environmental affects, eutrophication, bacterial growth in drinking water, algal blooms interrupting tourism, and create dead zones in bodies of water resulting in the destruction of valuable fisheries [1]. Along with negative environmental effects the United States Environmental Protection passed regulations to reduce phosphorus in the Chesapeake Bay watershed by $24 \%$ by 2025 . It is imperative that quick inexpensive ways of phosphorus reduction be examined for various wastewater from municipal, agriculture, manufacturing, recreational, and household sources.

One possibility is hydrodynamic cavitation which is a combination of an increase in flow velocity creating a low-pressure zone over an object or by the motion of an object through that liquid creating a low pressure zone that produces hydrodynamic cavitation [2]. Cavitation is created when the localized area of low pressure falls below that liquids vapor pressure; once the vapor pressure is decreased below this point a vapor filled void is developed [3]. Resulting in what in appearance is a bubble. This localized area contains pressure below the vapor pressure causing the space to have atomized liquid caused by that liquid boiling below the liquids pressure. This vapor filled low pressure void will continue to grow until an unsustainable size is reached. Once this void of vapor reaches an unstable size implosion begins to occur first intrusion of a micro-jet of liquid through the center of void, which than creates momentum to quicken the collapse [4]. This micro-jet carries through and forms a shock wave. This implosion concentrates the energy created by the formation of the cavitation void upon collapse reaching temperatures and pressures approaching of $5000^{\circ} \mathrm{C}$, and 2000 atm. [5,6]. Along with pressure and temperature hydrodynamic cavitation increase turbulent flow, Reynolds numbers, and creates an increase in sheer forces from the high velocities of liquid flow involved [7].

Hydrodynamic cavitation can be induced by impellor, a ship's rudder creating a hydrofoil, jets of liquid, and pushing a flow of water through an orifice, which is a plate of smaller openings than that of the pipe diameter the plate is seated in (Rhee and Kim 2008 [8].

Since movement of liquid or movement of the container is relative, during the creation of liquid velocity one can move, vibrate or oscillate the container holding a liquid or an object held within that liquid as such is the case with ultra-sonic baths and probes. The high frequency produced from oscillation can create cavitation as the container or probe moves quickly. This is often referred to as acoustic cavitation and is generally associated with acoustic or sono-chemistry [9].

\subsection{Types of Phosphate Removal}

There are several different and proven methods that are used to remove phosphates from wastewater allowing for the reduction of negative environmental factors cause by excess phosphate. These methods include using biologic, chemical, physio-chemical, crystallization, ion exchange, adsorbents / sorbents, and many other methods that are being developed to alleviate the issue of high phosphate content in wastewater [10].

\subsubsection{Aluminum}

Aluminum is often used in phosphate removal aluminum sulfate (alum) a widely and commonly available product that is used in many industries which undergoes the following reaction [11].

$$
\begin{aligned}
& \mathrm{Al}_{2}\left(\mathrm{SO}_{4}\right)_{3} 14 \mathrm{H}_{2} \mathrm{O}+2 \mathrm{PO}^{3-}=2 \mathrm{AlPO}_{4}+3 \mathrm{SO}^{2-} \\
& +14 \mathrm{H}_{2} \mathrm{O}
\end{aligned}
$$

Like all reactions, the dosage of aluminum sulfate depends upon the concentration of soluble phosphate, contaminates and particles within the wastewater. Alum will aid flocculation of solid contamination. The reaction between alum and phosphate is thermodynamically and kinetically favored over aluminum hydroxide formation. This makes aluminum sulfate an attractive and easy to use chemical additive for wastewater treatment. Like many other forms of chemically aided phosphate removal $\mathrm{pH}$ is a factor when wastewater is treated. For effective removal, hydroxide ions must be added in some form to buffer the aluminum sulfate with acidic wastewaters. Aluminum phosphate the product of wastewater treatment with alums is not soluble in water but like many phosphate containing salts is acid soluble.

\subsubsection{Iron}

Iron (III) or iron (II) can be reacted with $\mathrm{HCl}$ to produce ferric and ferrous chloride respectively. Ferric chloride and Ferrous Chloride are used in much the same way the calcium is used in the 
removal of phosphates. They react with phosphate in wastewater and are than neutralized to precipitate phosphates as iron salts. Chemical factors of wastewater $\mathrm{pH}$, oxygen concentration, catalytic activity and presence of inhibitory substances, e.g. Sulphur all effect the reduction of phosphate in wastewater with the use of ferric chloride. Iron (III) ions form strong complexes with pyrophosphate and tripolyphosphates e.g.. Chemical equation 2, which are then probably removed by adsorption onto iron (III) hydroxy-phosphate surfaces $[11,12]$. The use of ferric chloride is growing as a water treatment option in the United States and around the world.

$$
\begin{aligned}
& \mathrm{FeCl}_{3}(\mathrm{aq})+\mathrm{Na}_{3} \mathrm{PO}_{4}(\mathrm{aq}) \rightarrow \mathrm{FePO}_{4}(\mathrm{~s})+3 \\
& \mathrm{NaCl}(\mathrm{aq})
\end{aligned}
$$

\subsubsection{Sorbents/ absorbents}

Using ion exchange resins nearly $95 \%$ of phosphate removal was achieved in controlled lab scale experiments [13]. Although a high amount of phosphates can be removed in this manner the use of sorbents or absorbents can be difficult expensive and may require a high technical knowledge to work with. Also, because this type of phosphate removal may require expensive materials that have a temporary service span, chemicals for cleaning and then must be discarded after their life is over. The viability for municipal use is less likely. With other forms of phosphate removal, it is possible to produce useful and resalable chemicals like calcium phosphate that can be used in farming and gardening. This is not the case in ion exchange chromatography.

\subsubsection{Biologic phosphate removal}

Using microbes both eukaryote like ameba, yeasts, and protists along with prokaryotes like bacteria in activated sludge operations is a proven and commonly used method to not only remove phosphates in wastewater it is also a proven way to remove ammonia in wastewater. The microorganisms use the phosphate in their cellular functions and cellular structures, they then die settle to the bottom and can be disposed of contain the phosphate formally in waste water. These operations are known as activated sludge operations. Activated sludge operation use anaerobic and aerobic phase to maximize phosphate removal [14]. Under anaerobic conditions phosphates are released from the sludge into solution the two phases grow many different species of microorganisms' part require and cannot live without oxygen, in the other phase microorganisms are killed by oxygen. Aeration induces the sludge to take up phosphates from the solution more than normal metabolic requirements. Wastewater treatment plants using activated sludge methods for phosphate removal can remove up to $90 \%$ of phosphates.

Algae of the species Cladophora glomerata and Vaucheria can reduce phosphorous in waste water by over $50 \%$ if applied to a trickling filter [15].

Another self-sustaining use of biologic phosphate removal and other types of contaminant removal is the use of wetlands and constructed wetlands. Wetlands have been shown to be an extremely effective tool in the removal of phosphates in wastewater. Removal of phosphates in wastewater is on the order of $98-100 \%$ removal in wetlands [16]. Wetland update of phosphates is found to be the same in both constructed and natural wetlands. The biology in wetlands that metabolizes and removes phosphates is complex and not completely known. What is known is that wetlands are extremely rich and diverse environments where competition for metabolites like phosphates is high. This is what explains the $98-100 \%$ rate of phosphate removal between wetland input and output.

\subsubsection{Calcium based removal}

Quick lime or calcium oxide are the most common calcium salt used for phosphorus precipitation, this reaction generally forms hydroxyapatite chemical equation 3. Calcium hydroxide and other forms of calcium containing molecules can be modified or chemical reacted with phosphate to precipitate phosphate out of solution. Factors like $\mathrm{pH}$, saturation of the phosphate containing solution with excess calcium, the presence of 'seeds' or super nuclei to create a base for crystal formation all factor into the amount of calcium and phosphate reacting [17]. It has been observed that the lack of hydroxide $(\mathrm{OH}-)$ ions inhibit the formation of calcium salts suggested $\mathrm{pH}$ range of 7.5 to 11.0 is there for recommended [18,19]. Furthermore, most calcium salts are soluble in acidic solutions starting as low as $\mathrm{pH}$ 6.5. When using lime or calcium hydroxide some phosphate will react with the available calcium, however reaction rates and yields are initially low but the rate and yield is aided by supersaturation [18]. 
Supersaturation allows of settling and the reuse of calcium rich bases like $\mathrm{Ca}(\mathrm{OH})_{2}$ or lime, and calcium phosphate salts. The reuse of these materials and the salts they produce also allows for super nucleation. Also known as seeding, super nucleation forms the corner stone for the building of crystal lattice structure, as one block is laid and mass grows that super nuclei quickly grows into larger calcium phosphate salts [20]. Carbon dioxide is also important in the removal of phosphates from wastewater De Boice \& Thomas calcium is thought first to precipitate calcium carbonate in the presence of high concentrations of hydroxide ions e.g. Chemical equation 4or in other solutions, bicarbonate, these constituents form from carbon dioxide addition any excess calcium then precipitates phosphate. Other advantages of this include removal of atmospheric $\mathrm{CO}_{2}$ if outside air is used in the reaction, also the high $\mathrm{pH}$ is neutralized and the effluent can be made ready for reintroduction into the environment.

$$
\begin{aligned}
& 10 \mathrm{Ca} 2++6 \mathrm{PO} 3-+2 \mathrm{OH} \rightarrow \sim-' \sim \mathrm{Ca}_{10}(\mathrm{PO} 4)_{6} \\
& (\mathrm{OH})_{2} \\
& \mathrm{Ca}(\mathrm{OH})_{2}+\mathrm{CO}_{2} \rightarrow \mathrm{CaCO}_{3}+\mathrm{H}_{2} \mathrm{O}
\end{aligned}
$$

It is possible to reduce the concentration of phosphate in wastewater with the use of calcium hydroxide chemical equation 5 . Although simply mixing an amount in of excess amount of $\mathrm{Ca}(\mathrm{OH})_{2}$ with a sample containing phosphate will generally only yield a fraction calcium phosphate production that the balanced equation shows. This is most likely due to the poor solubility in water, combined with decreasing solubility with increasing temperature- $0.189 \mathrm{~g} / 100 \mathrm{~mL} 0^{\circ} \mathrm{C}$, $0.173 \mathrm{~g} / 100 \mathrm{~mL} 20^{\circ} \mathrm{C}, 0.066 \mathrm{~g} / 100 \mathrm{~mL} 100^{\circ} \mathrm{C}$. Additionally calcium hydroxide is a solid and forms course conglomerates when it's dry. There for when put into solution the larger the surface area of the solid the longer it takes to dissolve $\mathrm{Ca}(\mathrm{OH})_{2}$.

$$
\begin{aligned}
& 3 \mathrm{Ca}(\mathrm{OH})_{2}+2 \mathrm{NH}_{4} \mathrm{H}_{2} \mathrm{PO}_{4} \rightarrow \mathrm{Ca}_{3}(\mathrm{PO} 4)_{2}+ \\
& 2 \mathrm{NH}_{3}+6 \mathrm{H}_{2} \mathrm{O}
\end{aligned}
$$

To overcome the issue of low solubility and large surface area hydrodynamic cavitation can be used. Cavitation has been shown to increase the kinetics calcium hydroxide by temporarily increasing temperature of calcium hydroxide in turn increasing dissociation of surface molecules helping to alleviate the problem of poor solubility [21]. Hydrodynamic dynamic cavitation allows for greater dissociation of surface molecules by causing the violent collapse of vapor filled cavities. These vapors filled cavities expands until an unstable size is reached and upon collapse reaches temperatures and pressures approaching of $5000^{\circ} \mathrm{C}$, and $2000 \mathrm{~atm}$ [22]. Along with pressure and temperature hydrodynamic cavitation increase turbulent flow, Reynolds numbers, and increase in sheer forces and the ability to physical alter surface of calcium hydroxide that these voids come in contact with. It is probable that phosphate and calcium hydroxide can react directly on the surface of the calcium hydroxide particles after surface disassociation. Yavors'kyi hypotheses [21] the cavitation can create $\mathrm{Ca}(\mathrm{OH})_{2} \rightarrow \mathrm{Ca}(\mathrm{OH})^{+}$on the surface of calcium hydroxide. This phisochemical reaction may provide a base for the formation of calcium phosphate salts on the surface of the $\mathrm{Ca}(\mathrm{OH})_{2}$ when phosphate is present in the solution. This combined with cavitation action continuously removing newly formed salts and reforming $\mathrm{Ca}(\mathrm{OH})^{+}$may allow for the reuse of calcium hydroxide in this reaction and the collection of the calcium phosphate salts for industrial use.

\subsection{Project Scope}

In this research project, a continuous flow process was examined as a possible alternative for phosphate removal for large scale industrial, municipal and agricultural process applications. The research project investigated two forms of hydrodynamic cavitation produced by jet nozzles and orifice plates using calcium hydroxide as chemical reactant.

\section{MATERIALS AND METHODS}

\subsection{Waste Water and Cavitation Apparatus}

Phosphor content of waste water was simulated by adding $3.50 \mathrm{~g}$ of ammonium dihydrogen phosphate from Bean Town Chemicals to $30 \mathrm{~L}$ of tap water stored in the influent tank of the hydrodynamic cavitation set up Fig. 1. The artificial wastewater containing a $50 \mathrm{mg} / \mathrm{l}$ of $\mathrm{PO}_{4}$ was than pumped through 1 inch tubing using a Dyton model 3YU60A brand .5hp pump, to a static mixing flange designed to, mix and cavitate calcium hydroxide as shown in Fig. 1.

The total length of this apparatus was $1.10 \mathrm{~m}$, and included a 10:1 Venturi pump for the introduction of $20 \%$ wt calcium hydroxide $\left(\mathrm{Ca}(\mathrm{OH})_{2}\right)$ slurry. The $\mathrm{Ca}(\mathrm{OH})_{2}$ slurry was made 


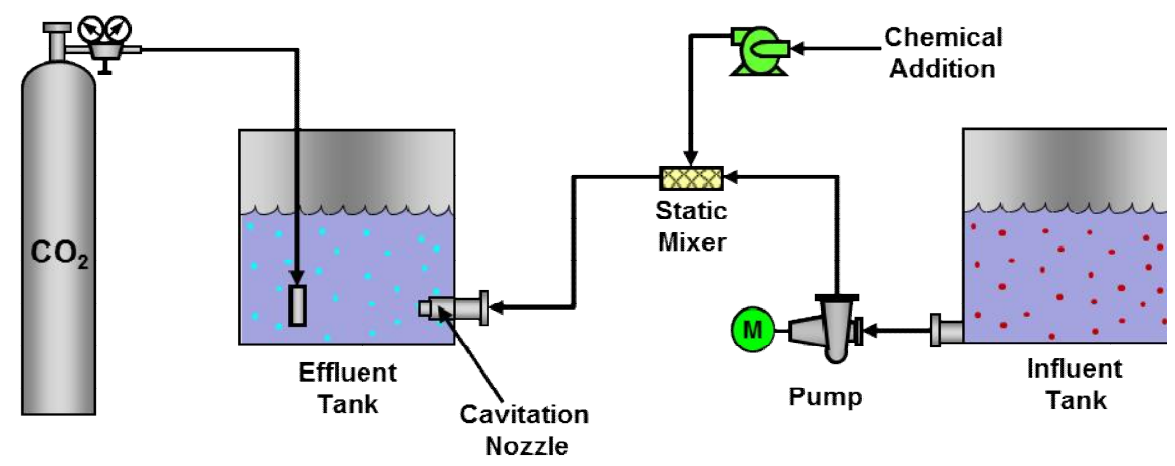

Fig. 1. Process sketch of hydrodynamic cavitation set up

from Sig-Aldrich brand $\mathrm{Ca}(\mathrm{OH})_{2}$ and $80 \%$ wt tap water and pumped using a paulsetronic brand parasitic pump at rate of $80.00 \mathrm{ml} / \mathrm{min}$ or 16.00 $\mathrm{g}$ of $\mathrm{Ca}(\mathrm{CO})_{2}$ diluted slurry per minute. The slurry was continually stirred during the experiment and hoses purged with tap water after each run to prevent settling with in the lines.

After the Venturi pump the slurry entered a commercially available pvc static mixing flange. The remainder of the unit was 1" PVC pipe with a pressure gauge and temperature gauge. The same unit was used in all experiments, but modified for orifice plate cavitation and jet nozzle cavitation.

\subsection{Orifice Plate Design}

Two orifice plates were constructed of machined aluminum. One containing $19,1 \mathrm{~mm}$ holes in a one inch diameter circular area (Fig. 2a), to be evenly spaced out over the inner diameter of the PVC pipe, and were modeled after the orifice plates designed by Vichare et al. [23]. This created a flow rate of $13 \mathrm{l} / \mathrm{min}$ at $47.5 \mathrm{psi}$. A second containing 19, $2 \mathrm{~mm}$ holes (Fig. 2b) creating a flow rate of $60 \mathrm{l} / \mathrm{min}$ at $5 \mathrm{psi}$. The rate of chemical addition remained the same. The jets of water produced by the orifice plate were introduced into the wastewater pond at the bottom (Fig. 2).

\subsection{Jet Nozzle Cavitation}

Jet cavitation was conducted using the identical apparatus, but the flange holding the orifice plate was replaced with a $1 / 2$ in PVC "T" adapter connecting two $3 / 4$ " inner-diameter 5 foot tubes connecting to two identical nozzles. In trial one two $9 \mathrm{~mm}$ nozzles were used than followed in the next trial by two $4 \mathrm{~mm}$ jet nozzles were used to cavitate wastewater. Each tube was attached to an adjustable bevel that could easily be fixed at angels $90^{\circ}, 120^{\circ}, 150^{\circ}, 180^{\circ}$, both size nozzles were arranged in this manner. Fig. 3 shows the $90^{\circ}$ arrangement. Once trials with the $9 \mathrm{~mm}$ and $4 \mathrm{~mm}$ nozzle sizes and 5 foot tubing we completed and analyzed the length of one hose was shortened, and jet nozzles were set to $90^{\circ}$ the most efficient angle to reduce phosphate. This produced a near continual flow of $\mathrm{Ca}(\mathrm{OH})_{2}$. Shortening the hose length is done to offset the timing of $\mathrm{Ca}(\mathrm{CO})_{2}$ delivery by the peristaltic pump. With even tubing length pulses of $\mathrm{Ca}(\mathrm{CO})_{2}$ were delivered simultaneously. By calculating the velocity of water in the system and timing the delivery of each delivered $\mathrm{Ca}(\mathrm{OH})_{2}$ pulse from the peristaltic pump, the hose could be cut to deliver calcium hydroxide pulses $180^{\circ}$ out of phase. This was confirmed mathematically and by the addition of colored dye which could be seen moving through the clear tubing.

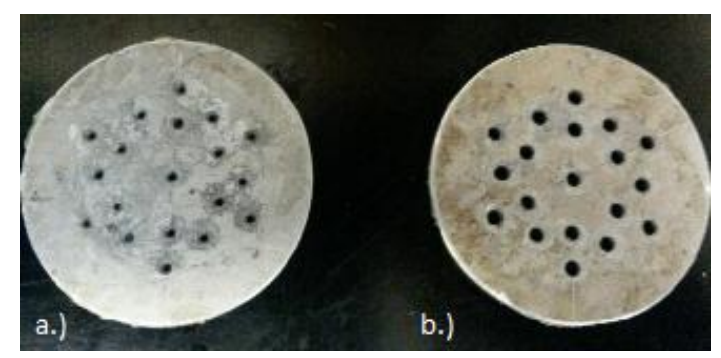

Fig. 2. Orifice plates used to produce cavitation

a.) $1 \mathrm{~mm}, 19$ holes b.) $2 \mathrm{~mm}, 19$ holes

\subsection{Detecting the Presence of Cavitation}

The presence of cavitation was confirmed using solution of $0.5 \mathrm{M} \mathrm{KI}$ Bean Town Chemicals in tap water was used to verify cavitation. KI was used in the identical apparatus as the manufactured 
wastewater and calcium hydroxide. The disassociation of $\mathrm{KI}$ is a known indicator of cavitation by measuring the change in absorbency caused by the dissociation of potassium from iodine incited via cavitation [23]. The change of absorbency is measured using a Hach DR 1900b portable spectrometer at 355 $\mathrm{nm}$. This method of measuring the change in absorbency at $355 \mathrm{~nm}$ was used to confirm cavitation in all methods. lodine has a color absorbency around $355 \mathrm{~nm}$; the higher the absorbency the more iodine that is dissociated or released by the ionic potassium iodide salt [23].

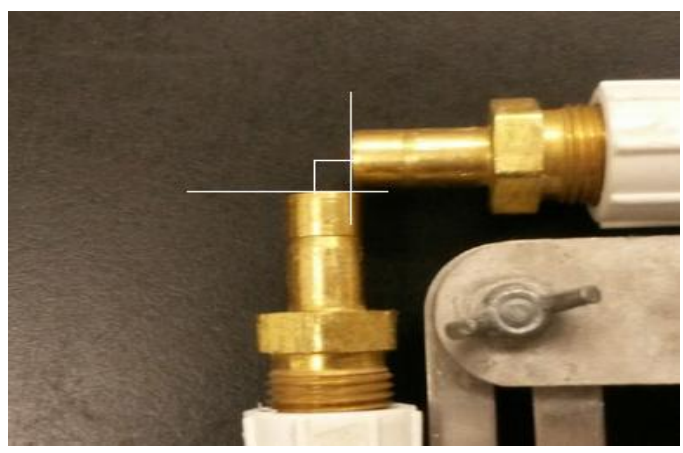

Fig. 3. Example of Jet Nozzle setup at $90^{\circ}$

\subsection{Sampling and System Cleaning}

A total of three samples were taken for testing in all trials: The first sample was collected from the influent tank (Fig. 1) to confirm the amount of phosphate in the manufactured waste water prior to treatment. The second sample was collected from the effluent tank before the jet nozzles became submerged. In both cases the set up used for nozzle and orifice plate cavitation approximately $5 \mathrm{~cm}$ existed between the bottom of the container and where jet nozzles and the orifice plate were located. The third sample was collected from the effluent tank at the completion of the experiment to test the treated wastewater. To verify the exact concentration of phosphorus at each step the Hach Test n' Tube High Range Reactive Phosphate 0-100 mg/L Hach reagent set \#2767345, and read on the preprogrammed Hach DR 1900b portable spectrometer following manufacture methods and procedures. All sample to be tested by this method were taken from the middle of the sampling vessel as to collect as little calcium hydroxide as possible.

After each trial the wastewater containers, catch basin and apparatus were rinsed and cleaned to remove as much ammonium dihydrogen phosphate and $\mathrm{Ca}(\mathrm{OH})_{2}$ as possible. The catch basin and manufactured wastewater pond are first triple rinsed with tap water than rinsed with a $0.5 \mathrm{M}$ hydrochloric acid solution. The pump and $\mathrm{Ca}(\mathrm{OH})_{2}$ mixing apparatus were rinsed through the Venturi pump with tap water where $\mathrm{Ca}(\mathrm{OH})_{2}$ is introduced for a minimum of 5 minutes. Collection and test vessels were rinsed with $6 \mathrm{M}$ $\mathrm{HCl}$ as per Hach testing specifications.

\subsection{Neutralization}

Removal of excess $\mathrm{Ca}(\mathrm{OH})_{2}$ and neutralization was done. Due to low solubility and supersaturation calcium hydroxide and produced calcium products settle very quickly. One liter of clear treated wastewater was collected from the waste water basin after being allowed to settle. A digital $\mathrm{pH}$ meter was submerged and $\mathrm{CO}_{2}$ gas bubbled through until neutralization occurred to a $\mathrm{pH}$ of approximately 8.0.

\subsection{Waste Water Application}

The hydrodynamic test apparatus was tested using municipal wastewater at the CERF facility located at wastewater treatment plant of the Village of Minoa, New York State. The Identical process was applied to municipal wastewater using the cavitation apparatus with $4 \mathrm{~mm}$ jet nozzles under a $90^{\circ}$ angle and applying calcium hydroxide as a reactant (Fig. 1). For analyses of the phosphate the Hach Test n' Tube high rang phosphate test was used as described in the materials and methods section. The phosphate concentration was averaged to be $29.01 \mathrm{mg} / \mathrm{L}$ of reactive phosphate in the wastewater. Applying the calcium hydroxide and cavitation method the amount of the phosphate was reduced to below $3.00 \mathrm{mg} / \mathrm{L}$. This achieved an $89.7 \%$ reduction of phosphate without $\mathrm{CO}_{2}$ neutralization.

\section{RESULTS AND DISCUSSION}

The use of jet nozzle cavitation and orifice plate cavitation produced a greater removal of phosphate than controls alone. The greatest method removed was 8.8 times more of a percentage of phosphate than the base control (Table 1). Factors influencing the removal of phosphate included, size of nozzle or orifice hole, continuous or alternating introduction of calcium hydroxide, and weather orifice plates or nozzles are submerged in treated wastewater. It should be noted that even before the orifice plate or jet nozzle is reached by the water, cavitation will 
occur between phosphate and $\mathrm{Ca}(\mathrm{OH})_{2}$ at the end of the Venturi and within the static mixing flange.

Table 1. Total percentage of phosphate removed by various method

\begin{tabular}{|c|c|c|}
\hline & Method & $\begin{array}{l}\% \mathrm{PO}_{4} \\
\text { removed }\end{array}$ \\
\hline \multirow[t]{3}{*}{$\begin{array}{l}\mathrm{Ca}(\mathrm{OH}) 2 \\
180^{\circ} \text { out of } \\
\text { phase }\end{array}$} & $\begin{array}{l}90^{\circ} 4 \mathrm{~mm} \text { Nozzle cut } \\
\text { tube with pH } \\
\text { Neutralization }\end{array}$ & 89.30 \\
\hline & $\begin{array}{l}90^{\circ} \text { Small } 4 \mathrm{~mm} \\
\text { Nozzle cut tube }\end{array}$ & 70.15 \\
\hline & $\begin{array}{l}90^{\circ} \text { Small } 4 \mathrm{~mm} \\
\text { Nozzle cut tube }\end{array}$ & 62.30 \\
\hline \multirow[t]{2}{*}{ Orifice plate } & $\begin{array}{l}\text { Orifice plate 19, } 1 \mathrm{~mm} \\
\text { holes }\end{array}$ & 58.89 \\
\hline & $\begin{array}{l}\text { Orifice plate 19, } 2 \mathrm{~mm} \\
\text { holes }\end{array}$ & 56.66 \\
\hline \multirow[t]{8}{*}{ Jet nozzle } & $\begin{array}{l}90^{\circ} \text { Small } 4 \mathrm{~mm} \\
\text { Nozzle }\end{array}$ & 53.23 \\
\hline & $\begin{array}{l}120^{\circ} \text { Small } 4 \mathrm{~mm} \\
\text { Nozzle }\end{array}$ & 47.64 \\
\hline & $\begin{array}{l}150^{\circ} \text { Small } 4 \mathrm{~mm} \\
\text { Nozzle }\end{array}$ & 29.74 \\
\hline & $\begin{array}{l}180^{\circ} \text { Small } 4 \mathrm{~mm} \\
\text { Nozzle }\end{array}$ & 9.56 \\
\hline & $\begin{array}{l}90^{\circ} \text { Large } 9 \mathrm{~mm} \\
\text { Nozzle }\end{array}$ & 21.00 \\
\hline & $\begin{array}{l}120^{\circ} \text { Large } 9 \mathrm{~mm} \\
\text { Nozzle }\end{array}$ & 16.90 \\
\hline & $\begin{array}{l}150^{\circ} \text { Large } 9 \mathrm{~mm} \\
\text { Nozzle }\end{array}$ & 17.00 \\
\hline & $\begin{array}{l}180^{\circ} \text { Small } 4 \mathrm{~mm} \\
\text { Nozzle }\end{array}$ & 3.42 \\
\hline \multirow[t]{3}{*}{ Controls } & $\begin{array}{l}\text { Control Jet large } 9 \mathrm{~mm} \\
\text { Jet Nozzles no angle }\end{array}$ & 15.91 \\
\hline & $\begin{array}{l}\text { Control Jet Small } 4 \\
\text { mm Jet Nozzles no } \\
\text { angle }\end{array}$ & 12.36 \\
\hline & Control Stirred Beaker & 10.56 \\
\hline $\begin{array}{l}\text { Jet nozzle } \\
\text { municipal } \\
\text { wastewater }\end{array}$ & $\begin{array}{l}90^{\circ} \text { Small Nozzle cut } \\
\text { tube }\end{array}$ & $>90.0$ \\
\hline
\end{tabular}

The use of a peristaltic pump first acted as what was though as a detriment to the experiment. Data collected sowed that the peristaltic pump does not deliver a continuous flow of the calcium hydroxide slurry. The pump delivers approximately $333 \mathrm{mg} /$ pulse. This turned out to be a control with useful information and insight about the effect of the physio-chemical reaction that is taking place between calcium hydroxide, phosphate, and cavitation. Using a peristaltic pump allowed us to observe a greater reduction in phosphate when $\mathrm{Ca}(\mathrm{OH})_{2}$ was delivered out of phase in a near continuous manner meaning more phosphate and $\mathrm{Ca}(\mathrm{OH})_{2}$ interacted under the physio-chemical conditions, compared to when the $\mathrm{Ca}(\mathrm{OH})_{2}$ was delivered in straight pulses. During pulse delivery, more time would have been spent without $\mathrm{Ca}(\mathrm{OH})_{2}$ and phosphate interacting under cavitation conditions.

When comparing mixing calcium hydroxide and phosphates in a beaker as a control to cavitation, data revealed it is probable that the forces formed by jets of water themselves did not directly affect the removal of $\mathrm{PO}_{4}{ }^{-}$, but it was the combination of $\mathrm{Ca}(\mathrm{OH})_{2}$ and $\mathrm{PO}_{4}{ }^{-}$in cavitation type conditions that produced the best removal of phosphate and formation of $\mathrm{Ca}_{3}(\mathrm{PO} 4)_{2}$ and other calcium salts. This result can be interpreted by comparing pulsed delivery of $\mathrm{Ca}(\mathrm{OH})_{2}$, with near continuous delivery. When pulse of $\mathrm{Ca}(\mathrm{OH})_{2}$ went through the identical length tubing reaching the jet nozzles at the same time $\mathrm{PO}_{4}{ }^{-}$was reduced by $53.23 \%$. When pulses of $\mathrm{Ca}(\mathrm{OH})_{2}$ reached the nozzles $180^{\circ}$ out of phase or nearly continuously, $\mathrm{PO}_{4}{ }^{-}$was reduced by $70.15 \%$. Both results were achieved with the $90^{\circ}$ angle and small $4 \mathrm{~mm}$ nozzle. Indicating that cavitation action on $\mathrm{Ca}(\mathrm{OH})_{2}$ molecules is more important to the removal of phosphate in the system than the amount of $\mathrm{Ca}(\mathrm{OH})_{2}$ present in the reaction. Although pumps and apparatus did not change pressure and there for time did vary. When using orifice plate cavitation flow rates were lowered meaning more time to pump the $30 \mathrm{~L}$ of manufactured waste water was needed, therefore more of $\mathrm{Ca}(\mathrm{OH})_{2}$ was introduced.

The angles of the nozzles influenced the amount of $\mathrm{PO}_{4}{ }^{-}$removed (Table 1). Angles tested using both $4 \mathrm{~mm}$ (Fig. 4) and $9 \mathrm{~mm}$ (Fig. 5) nozzles were $90^{\circ}, 120^{\circ}, 150^{\circ}, 180^{\circ}$. The trends of $\mathrm{PO}_{4}{ }^{-}$ removal were similar for both large and small nozzle trials. Jet nozzles held perpendicular or at $90^{\circ}$ to one another produced the greatest results. Jets at a $90^{\circ}$ most efficiently transfer energy into a ratio of maximum turbulent flow and the production of useful cavitation voids; that increase the dissociation of surface area alleviating the issue of poor solubility. At $90^{\circ}$ it is possible that the Venturi effect aids cavitation by maintaining a low-pressure area by quickly circulating liquid by the nozzle. With the Venturi effect taking place the super cavitation within the nozzle will be maintained, this will prevent flipping and collapse of super cavitation. Jets directed exactly towards one another or at $180^{\circ}$ seemed to have a negative effect on the removal of phosphate. This is most likely due to the loss 
of cavitation within the nozzle. As water is forced into the other nozzle velocity may be lost, and liquid will infiltrate the cavitation void causing collapse and loss of cavitation.

Similar phenomena resulting in the cancelation or reduction in the ability of cavitation to increase the rate of a reaction was observed during bench scale acid hydrolysis reactions by Losev et al. [24]. In their experiment, hydrodynamic cavitation effects were reduced what they hypothesized as resonance within the system. As propeller speeds increased so did the rate of reaction peaking at 4000 rpms and reducing after. It is possible to compare the rotation of a propeller, or jets of liquid because the same hydrodynamic cavitation type voids are produced [24].

Orifice plate cavitation is produced by forcing fluid through numerous or small holes into a body of standing fluid. In this experiment manufactured wastewater rich in $\mathrm{PO}_{4}^{-}$was mixed in an apparatus with $\mathrm{Ca}(\mathrm{OH})_{2}$ and forced through

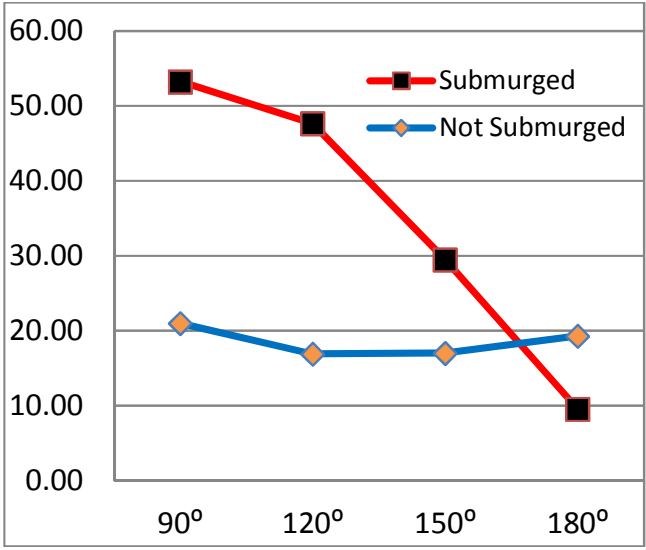

Fig. 4. Total percent $\mathrm{PO}_{4}^{-}$removed using $4 \mathrm{~mm}$ nozzle and submerged and not submerged
$1 \mathrm{~mm}$, and $2 \mathrm{~mm}$. The size and number of holes is proportional to that of plates made designed by Vichare et al. optimization of cavitation paper [23]. Experimentally orifice plate trial 1) with nineteen $1 \mathrm{~mm}$ holes removed more phosphate from wastewater than orifice plate trial 2) with nineteen $2 \mathrm{~mm}$ holes. The respective pressure, flow rate, velocities, and cavitation numbers $(\sigma)$ were $47.50 \mathrm{psi}$ and $13.00 \mathrm{~L} / \mathrm{min}$ total, $3.41 \mathrm{~m} / \mathrm{s}$, and $\sigma=.2765$ for each $1 \mathrm{~mm}$ hole; $7.5 \mathrm{psi}$ and $60.00 \mathrm{~L} / \mathrm{min}$ total, $16.75 \mathrm{~m} / \mathrm{s}$, and $\sigma=.2600$ for each $2 \mathrm{~mm}$ hole. Due to the large difference in flow rate the time to empty the $30 \mathrm{~L}$ influent tank was 138 s versus 30.00 s respectively, the amount of $\mathrm{Ca}(\mathrm{OH})_{2}$ available in total may have influenced the difference phosphate reacted to calcium phosphate. The amount of $\mathrm{Ca}(\mathrm{OH})_{2}$ injected into the system was $46.20 \mathrm{~g}$ for the $1 \mathrm{~mm}$ holes verse 10.00 grams for the $2 \mathrm{~mm}$ holes trial. Having greater amounts of $\mathrm{Ca}(\mathrm{OH})_{2}$ in the trial 1 system could be the reason for the increased removal of phosphate opposed to the small difference in cavitation numbers.

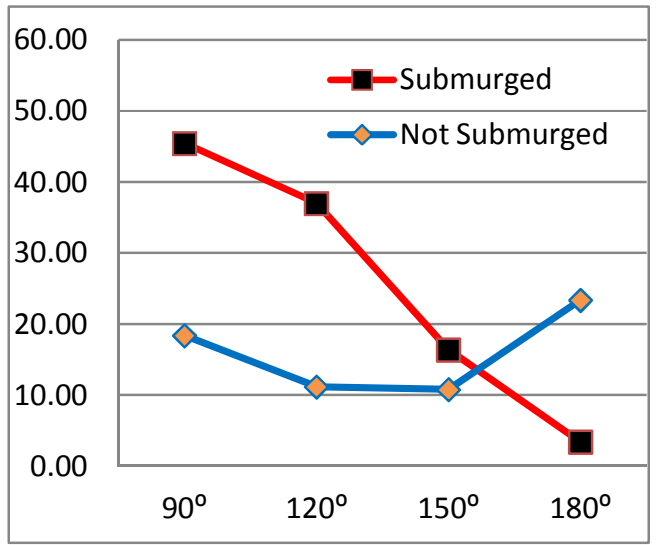

Fig. 5. Total percent $\mathrm{PO}_{4}{ }^{-}$removed using $9 \mathrm{~mm}$ nozzle submerged and not submerged

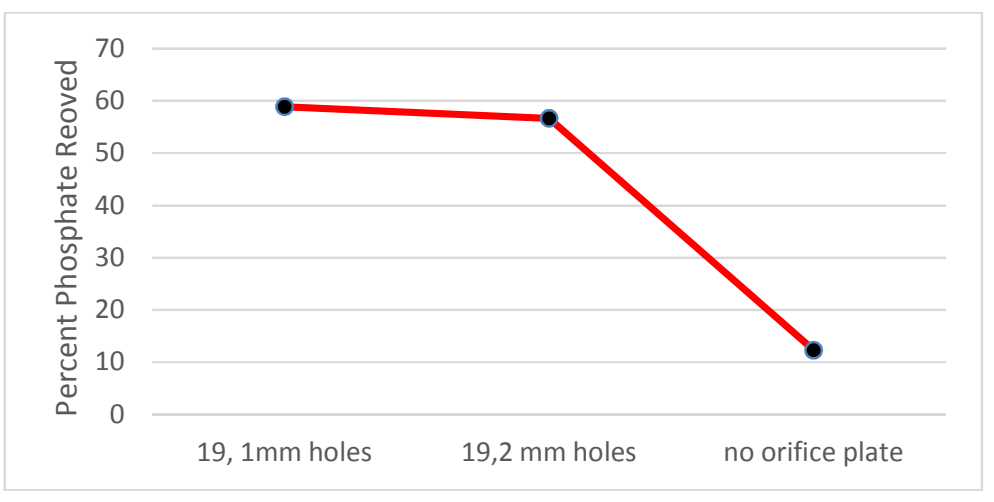

Fig. 6. Reduction of phosphate via orifice plate cavitation 
In all experiments use of excess calcium hydroxide not only provides ample surface area for cavitation to effect phosphate reduction, it also provides supersaturation of the wastewater solution and may promote the growth of calcium phosphate related crystals. These crystals will also precipitate out of solution and along with excess calcium hydroxide it will more quickly fall out of solution because of super saturation [19].

As this experiment aims to produce a viable and cheap solution to the issue of phosphates in wastewater, the effect of neutralization of Calcium Hydroxide rich treated wastewater was conducted with $\mathrm{CO}_{2}$. First excess calcium hydroxide was settled out of the treated waste water, and any calcium hydroxide that collected on the surface of the treated waste water was recovered. Only the clear supernatant was used for neutralization. Than carbon dioxide gas was bubbled through the treated wastewater resulting is $\mathrm{Ca}(\mathrm{OH})_{2}+\mathrm{CO}_{2} \rightarrow \mathrm{CaCO}_{3}+\mathrm{H}_{2} \mathrm{O}$. This had three effects one bringing the $\mathrm{pH}$ from 12.30 to 7.35 , it also produced calcium carbonate, and helped reduce phosphate content further. During this neutralization, $\mathrm{Ca}(\mathrm{OH})_{2}+\mathrm{CO}_{2} \rightarrow \mathrm{CaCO}_{3}+$ $\mathrm{H}_{2} \mathrm{O}$, and in turn further reduced the amount of phosphate in the wastewater by a total of nearly $90 \%$. It is possible that during neutralization the formation of calcium carbonate also trapped phosphate within its structure as an impurity. It is probable that more phosphate would be removed if the $\mathrm{pH}$ of the neutralized solution was kept above 7.4 , the point which calcium phosphate salts become more soluble in an acidic solution [25]. It is very possible that this method of wastewater treatment may be just as effective as many of the currently used methods of wastewater like using ferric chloride.

Collection and reuse of excess calcium carbonate the produced calcium phosphate salt, and left over calcium hydroxide solids not only serves a cost saving purpose, there is also a chance that more calcium phosphate salts will be produced. This if from seeding or creating the presence of supercritical nuclei that lays the first building block for crystal growth. As calcium hydroxide is reused the amount of calcium phosphate presents in and on the calcium hydroxide will increase aiding in super nucleation.

To examine the hydrodynamic cavitation effect on real municipal wastewater, the wastewater treatment plant in Minoa, NY was visited and wastewater was run through the cavitation apparatus (Fig. 1). For this test, the $4 \mathrm{~mm}$ jet nozzle with a $90^{\circ}$ angle arrangement (Fig. 3) under submerged condition was used. $\mathrm{Ca}(\mathrm{OH})_{2}$ was supplied $180^{\circ}$ out of phase. The tested wastewater was not neutralized, yet a reduction of phosphate over $90 \%$ was achieved. The reason for this most likely has to do with the high number of contaminants contained in municipal wastewater that could enhance calcium phosphate formation through nukleation. Not only were solid contaminants present but the exact chemistry of the wastewater is unknown. The amount of reactive phosphate was tested but other contaminants were not. Jet nozzle cavitation did not only reduce phosphate, but quick flocculation, and settling of contaminates was observed in the effluent tank of the cavitation apparatus used. Flocculants settled both on top of the water and sank to the bottom of the effluent tank (Fig. 2) where collection could be made easy.

For further study of municipal treatment of wastewater, it would be recommended that $\mathrm{CO}_{2}$ neutralization of wastewater also occurred followed by further testing of $\mathrm{PO}^{4-}$ in the wastewater column. Additionally, tests to reuse the $\mathrm{Ca}(\mathrm{OH})_{2}$ should be conducted. Since the solubility if $\mathrm{Ca}(\mathrm{OH})_{2}$ is so low and $\mathrm{PO}^{4-}$ is attached to the surface of the calcium hydroxide particle sequential cavitation would break further down the calcium hydroxide particle. This would allow to produce calcium phosphate salts on the additional surface area available of the calcium hydroxide particle.

\section{CONCLUSION}

The likely hood that calcium hydroxide with the use of cavitation can be a viable means of wastewater treatment. With further research and optimization of wastewater treatment processes that utilizes calcium hydroxide to remove phosphate with hydrodynamic cavitation it is likely, that this method can compete on a percentage of removal basis with any current method of phosphate removal from wastewater. Areas of study that would be beneficial to the optimization process would be the confirmation of super cavitation within each nozzle used to process the wastewater. Flipping nozzle cavitation could be a detriment and available study into this phenomenon using angular jet cavitation. It is not known from this study if the venturi effect prevents the flipping action from forming. The venturi effect may aid super cavitation by preventing the collapse of the 
cavitation void due to the velocity of flow past each nozzle helping maintain the low-pressure environment.

Validation of the effectiveness when reusing calcium hydroxide and how many times it can be used before its effectiveness is reduced should be studied. Due to the formation of acid soluble calcium phosphate it is likely that a point will be reached, where the balance of calcium phosphate to calcium hydroxide will no longer form calcium phosphate at an industrially acceptable rate.

\section{ACKNOWLEDGEMENTS}

Authors are thankful to ESF TRINITY institute for providing project funding.

\section{COMPETING INTERESTS}

Authors have declared that no competing interests exist.

\section{REFERENCES}

1. Miettinen IT, Vartiainen T, Martikainen PJ. Phosphorus and Bacterial Growth in Drinking Water. Applied and Environmental Microbiology. 1997;63(8):3242-45.

2. Dular M, Griessler-Bulc T, GutierrezAguirre I, Heath E, Kosjek T, Klemenčič AK, Oder $M$, Petkovšek $M$, Rački $N$, Ravnikar $M$, Šarc $A$, Širok $B$, Zupanc $M$, Žitnik M, Kompare B. Use of hydrodynamic cavitation in (waste) water treatment. Ultrasonics Sonochemistry. 2016;29:577588.

3. Plesset MS. The dynamics of cavitation bubbles. Journal of Applied Mechanics. 1949;16:277-82.

4. Lauterborn W, Bolle H. Experimental investigations of Cavitation-bubble collapse in the neighborhood of a solid boundary. Journal of Fluid Mechanics. 1975;72(2):391-399.

5. Mason TJ. Ultrasound in Synthetic Organic Chemistry. Chemical Society Reviews. 1997;26(6):443-51.

6. Suslick KS. The chemical effects of ultrasound. Scientific American. 1989; 260(2):80-86.

7. Soteriou C, Richard A, Smith M. Direct injection diesel sprays and the effect of cavitation and hydraulic flip on atomization. Society of Automotive Engineering, Inc. Technical Paper 950080. 1995;25-52.
8. Rhee $\mathrm{SH}$, Kim HJ. A suggestion of gap flow control device for the suppression of rudder cavitation. Journal of Marine Science and Technology. 2008;13:356370.

9. Moholkar VS, Senthil Kumar P, Pandit AB. Hydrodynamic cavitation for sonochemical effects. Ultrasonics Sonochemistry. 1999; 6:53-65.

10. Morse GK, Brett SW, Guy JA, Lester JN. Review: Phosphorus removal and recovery technologies. Science of the Total Environment. 1997;212(1):69-81.

11. Jenkins $D$, Ferguson JF, Menar AB. Chemical processes for phosphate removal. Water Research. 1971;5(7):36989.

12. Correa-Murrieta MA, López-Cervantes J, Sánchez-Machado DI, Sánchez-Duarte RG, Rodríguez-Núñez JR, NúñezGastélum JA. Fe(II) and Fe(III) adsorption by chitosan-tripolyphosphate beads: Kinetic and equilibrium studies. Journal of Water Supply: Research and Technology Aqua. 2012;61(6):331-41.

13. Lorenzo L, Boari G, Passino R. Phosphates and ammonia recovery from secondary effluents by selective ion exchange with production of a slowrelease fertilizer. Water Research. 1979; 13(1):65-73.

14. Taleyarkhan RP, Lapinskas J, Xu Y, Cho JS, Block RC, Lahey Jr. RT, Nigmatulin RI. Modeling, analysis and prediction of neutron emission spectra from acoustic cavitation bubble fusion experiments. Nuclear Engineering and Design; 2008.

15. Doelle K, Watkins C. Algae to remove phosphorous in a trickling filter. Journal of Advances in Biology \& Biotechnology. 2017;11(2):1-5

16. Aleksandra D, Forget C, Chapuis R. Phosphorus saturation potential: A Parameter for estimating the longevity of constructed wetland systems. Environmental Science \& Technology. 2002;36(21):4642-48.

17. Tadros ME, Skalny J, Kalyoncu RS. Papers Presented at the $49^{\text {th }}$ National colloid symposium, Clarkson kinetics of calcium hydroxide crystal growth from solution. Journal of Colloid and Interface Science. 1976;55(1):20-24.

18. Douglas $M$, Jorden $R$. Lime-induced reactions in municipal wastewaters. Water Pollution Control Federation. 1975;47(12): 2783-2808. 
19. Nikos S, Koutsoukos PG. The transformation of vaterite to calcite: Effect of the conditions of the solutions in contact with the mineral phase. Journal of Crystal Growth. 1998;191(4):783-90.

20. DeBoice JN, Thomas JF. Chemical treatment for phosphate control. Journal (Water Pollution Control Federation). 1975; 47(9):2246-55.

21. Yavors'kyi VT, Znak ZO, Mnykh RV. Influence of cavitation treatment on the physicochemical properties of calcium hydroxide. Materials Science. 2013;49(3): 368-74.

22. Mason TJ. Ultrasound in synthetic organic chemistry. Chemical Society Reviews. 1997;26(6):443-51.
23. Vichare NP, Gogate PR, Pandit AB. Optimization of hydrodynamic cavitation using a model reaction. Chemical Engineering \& Technology. 2000;23(8): 683-90.

24. Losev NV, Makarova LI, Lipatova IM. Rate of acid hydrolysis of starch as influenced by intensive mechanical effects. Russian Journal of Applied Chemistry. 2016;76(6): 997-1001.

25. Nikos S, Koutsoukos PG. The transformation of vaterite to calcite: Effect of the conditions of the solutions in contact with the mineral phase. Journal of Crystal Growth. 1998;191(4):783790.

(c) 2017 Dölle and Bargen; This is an Open Access article distributed under the terms of the Creative Commons Attribution License (http://creativecommons.org/licenses/by/4.0), which permits unrestricted use, distribution, and reproduction in any medium, provided the original work is properly cited.

Peer-review history:

The peer review history for this paper can be accessed here: http://sciencedomain.org/review-history/19014 